\title{
バリによる境界損傷の増大とその抑制*
}

\author{
新井実** 中山一雄**
}

Key words : metal cutting, boundary notch, burr, ceramic tool, stainless steel

1.はじめに

実際の生産加工に抢ける切削工具の寿命は平均的な 逃げ面摩耗やクレータ摩耗よりも境界損傷によって決 まることが多いから，工具寿命の延長のためには境界 損傷の抑制が重要である。ところが，境界損傷につい てはまだ不明な点が多く，その生成原因に対してすら 多数の全く異なる説が並存している1).

これらの一つに“延性材料の切削では切削ばりが境 界損傷の原因である”とする奥島らの説2)がある. しか しこれと反対に境界損傷が生ずるとバリが発生しやす くなる，すなわち，バリは境界損傷の結果であること も容易に想像できる。境界損傷が発生する原因はおく として，一度発生すればこれがバリを生じさせ，その バリが工具の境界部をたたいて増大させ，それがまた バリを増大させる，といった悪循環が存在することは 確かなようである。そこでこの悪循環を絶ち切るため に，切削中に生ずるバリを除去してみたら，境界損傷 の進展速度が著しく低下することが実験的に発見され たので報告する。

\section{2. 切削バリと境界損儩}

\section{1 境界損傷を起こしやすいエ 具と被削材}

まず工具と被削材の組合せによる 境界損傷の発生状況の差を調べる実 験を行った。切削は丸棒の長手乾旋 削で表 1 の下に示す条件で行った。 切削時間は境界損傷の激しい場合は $30 \mathrm{~s}$ ，激しくない場合は $3 \min$ (一部 では $2 \mathrm{~min}$ )とし, 横切れ刃の境界損

* 原稿受付 昭和 60 年 9 月 6 日. 昭和 58 年度精機学会春季大会学術講演会 （昭和 58 年 3 月 29 日）にて発表

** 正会員横浜国立大学工学部 (横 浜市保土ヶ谷区常盤台 156)
傷部の幅 $V N$ （図 1) を測定した。その結果が表 1 で, ステンレス鋼 SUS 304 に対しては，同表 a)で分かる ようにセラミックス $\left(\mathrm{Al}_{2} \mathrm{O}_{3}+\mathrm{TiC}\right.$, いわゆる黒七ラ） で削る場合の境界損傷が最も激しく, サーメットがこ れに次ぐが，超硬合金，中でもじん性の高いP 30 では きわめて少ないことがわかる†. 被削材としては，同表 b)に見られるように, SUS 304 が特に激しい境界損傷 を起こした。

\section{2 境界損伤の発達と切削バリ}

図 1 は各切削時間における観察をもとにして境界損 傷の発達状況をスケッチしたものである。境界損傷は わずか $5 \mathrm{~s}$ の切削でも観察され，切削幅の外縁から，外 へ外へと拡大する，図 2 はバリの生成状況を示したも ので，その外周部はひきちぎられた様相を呈している。 これはバリが成長するに伴ってその外周近傍は円周方 向の引張り力を受け，ひきちぎられたためであるが， このようなバリが工具の境界部をたたきながら擦過 し，境界損傷を起こすものと考兄られる。な拉，図1の 切削試験で各切削時間に括けるバリの高さの最大値を 測定したところ境界損傷のひろがり Cに浪等しい ことが見い出された。

Table 1 Effects of tool and work materials on the length of boundary notch $V N$

a) Effect of tool materials on $V N$ (work material ; SUS 304)

\begin{tabular}{l|c|c||c|c|c}
\hline Tool material & $\begin{array}{c}\text { Ceramics } \\
\left(\mathrm{Al}_{2} \mathrm{O}_{3}+\mathrm{TiC}\right)\end{array}$ & $\begin{array}{c}\text { Cermet } \\
(\mathrm{TiC})\end{array}$ & $\begin{array}{c}\text { Carbide } \\
\mathrm{P} 10\end{array}$ & $\begin{array}{c}\text { Carbide } \\
\mathrm{P} 30\end{array}$ & $\begin{array}{c}\text { Carbide } \\
\text { TiC coated }\end{array}$ \\
\hline Cutting time & $30 \mathrm{~s}$ & $30 \mathrm{~s}$ & $3 \mathrm{~min}$ & $3 \mathrm{~min}$ & $\begin{array}{c}3 \mathrm{~min} \\
\doteqdot 0\end{array}$ \\
$V N \mathrm{~mm}$ & 1.4 & 0.18 & 0.16 & $\begin{array}{c}\text { coated layer } \\
\text { flaked off }\end{array}$ \\
\hline
\end{tabular}

b) Effect of work materials on $V N$ (tool material ; ceramics)

\begin{tabular}{l|c||c|c|c|c}
\hline Work material & SUS 304 & SUS 303 & $0.7 \mathrm{C} / 7 \mathrm{Mn}$ st. & SCM 435 & SNCM 625 \\
\hline Cutting time & $30 \mathrm{~s}$ & $3 \mathrm{~min}$ & $2 \mathrm{~min}$ & $3 \mathrm{~min}$ & $3 \mathrm{~min}$ \\
$V N \mathrm{~mm}$ & 1.4 & 1.3 & 0.44 & $\doteqdot 0$ & $\doteqdot 0$ \\
\hline
\end{tabular}

Tool; TNPA $331(-5,-5,5,5,30,0,0.4)$

Cutting speed $; 100 \mathrm{~m} / \mathrm{min}$, Feed $; 0.1 \mathrm{~mm} / \mathrm{rev}$, Depth of cut $; 1 \mathrm{~mm}$

† CBN 工具もサーメットに近い境界損傷を起こした。 


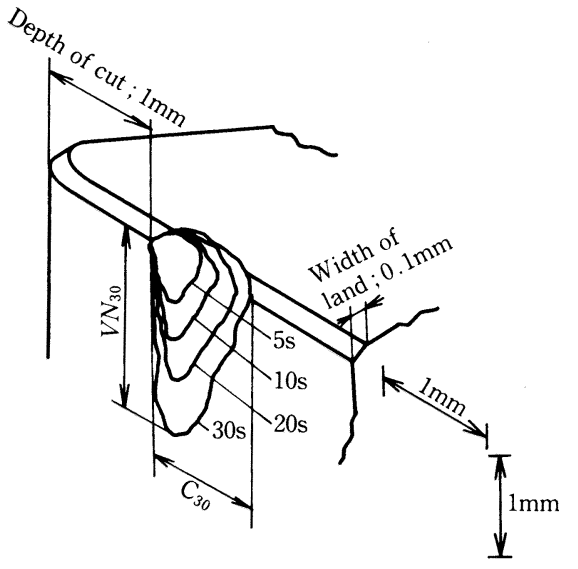

Fig. 1 Growth of boundary notch with cutting time Cutting speed $; 100 \mathrm{~m} / \mathrm{min}$, Feed $; 0.1 \mathrm{~mm} / \mathrm{rev}$, Depth of cut ; $1 \mathrm{~mm}$, Cutting tool ; ceramics $(-5,-5,5,5,30,0$, 0.4 ), Work material ; SUS 304

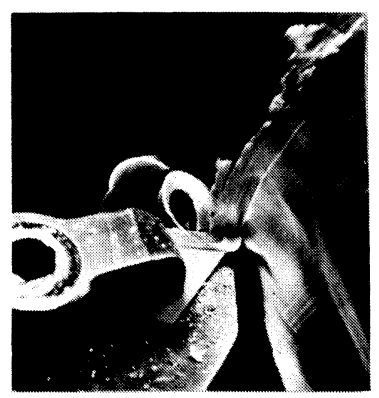

Fig. 2 Appearance of burr at the shoulder of workpiece

\section{3 切削バリの擦過試験}

実際に切削バリで境界損傷が起こるかどらかを確か めるために次の実験を行った.すなわち, 図 3 (a)に示

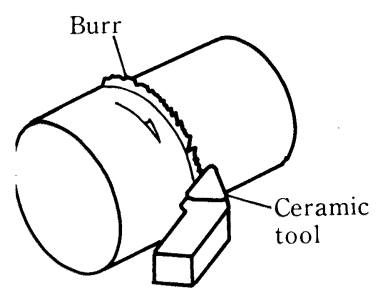

(a) Cutting tool-burr rubbing test

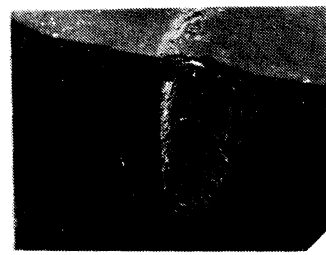

(c) After cutting $(100 \mathrm{~m} / \mathrm{min}, 30 \mathrm{~s})$

Fig. 3 Boundary notches on cutting tools made by rubbing and cutting

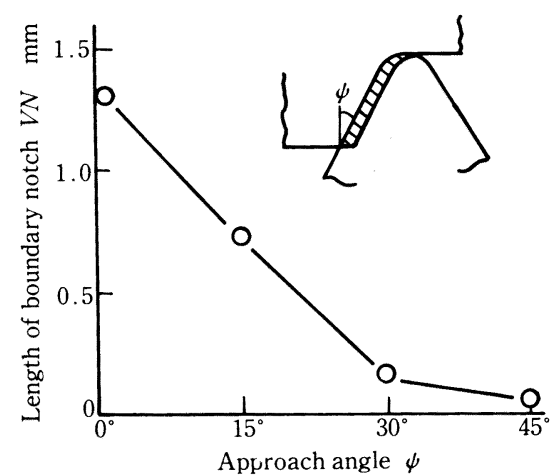

Fig. 4 Decrease of $V N$ with an increase of approach angle

Cutting conditions are the same as in Fig. 1 except for approach angle

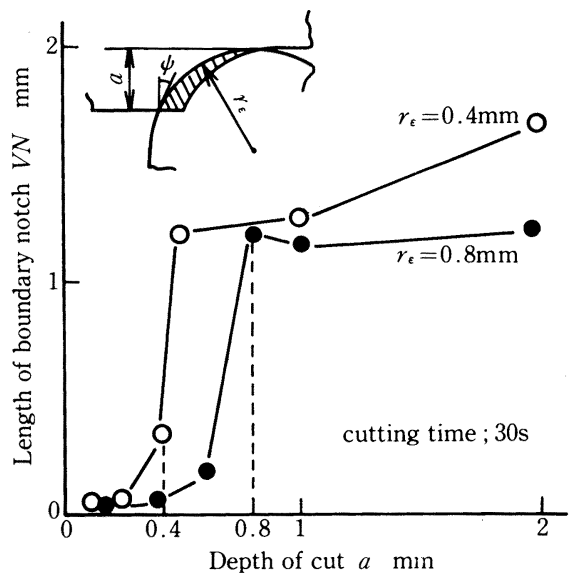

Fig. 5 Effects of corner radius' $r_{\varepsilon}$ and depth of cut $a$ on $V N$

Cutting conditions are the same as in Fig. 1 except for $r_{\varepsilon}$ and $a$

すよらに,バリを生じた工作物を回転させておき， そのバリの部分にセラミック工具を押し付けて擦 過させた。このとき生じた損傷が同図 (b) で, 同 図（c）に示す通常切削で生じた損傷と酷似してい る.

\section{3. バリ生成の抑制による境界損伤の減少}

以上から，工具の境界損傷を減らすにはバリの 生成を抑制すればよいことがわかる。これを実現 するために以下の 3 方法を試みた。

\section{1 アプローチ角の增大}

図4に示すように工具のアプローチ角 $\phi$ を増 すと工作物の肩部が鈍角になり，バリの生成が抑 制されて境界損傷が減少することが見い出され た。 また, 図 5 はコーナ半径 $r_{\varepsilon}$ の異なる 2 種類の 工具で切込み $a$ を変えて切削した結果である. 


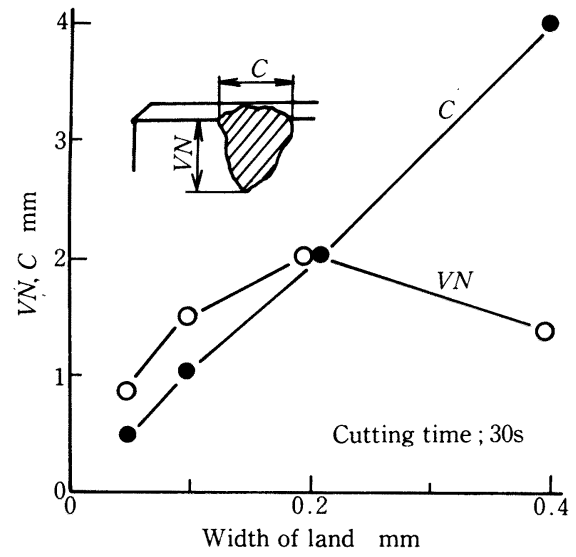

Fig. 6 Effect of width of land on $V N$ and $C$ Cutting conditions are the same as in Fig. 1

$a<r_{\varepsilon}$ では切込み $a$ が小さいほどアプローチ角が大 きくなり，損傷が著しく減るのがわかる.

\section{2 ネガランド幅の減少}

市販のセラミックチップにはランド角 $-35^{\circ}$, ランド 幅 $0.1 \mathrm{~mm}$ 程度の負のすくい角をもつランド（いわゆ るネガランド）がついているため，バリが生成しやす くなっていると思われる。 そこでランド幅を变えたセ ラミックチップを用いて旋削試験を行った。その結果 が図 6 で，ランド幅を減少すると境界損傷が著しく減 少することがわかる。

セラミックスなど比較的じん性の低い工具にはネガ ランドは必要不可欠であるが，切削バリによる境界損 傷といら面からみると, ランド幅が小さい方がよい。 このことはVigneau もインコネルの切削に対して指 摘3)している。

\section{3 バリとり切削}

切削点で生成したバリを図 7 (a) に示すよらに別の 工具で削りとりながら切削する“バリとり切削”を試 みた。その結果が同図 (b)で, 同じ条件で普通に削っ た結果の図 3 (c) と比べると境界損傷は著しく減少す るのがわかる。すなわち，境界損傷を増大させる原因 が切削バリであるといえる。この事実に基づいて，実 用的なバリとり工具を開発すれば境界損傷を減らすた

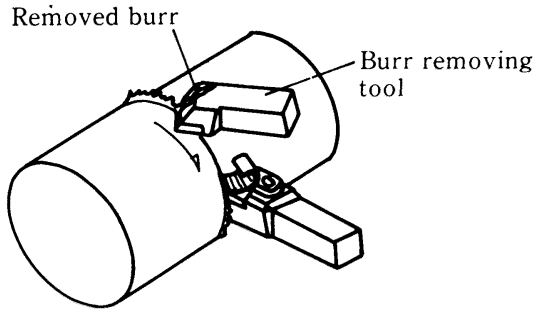

(a) Method of cutting

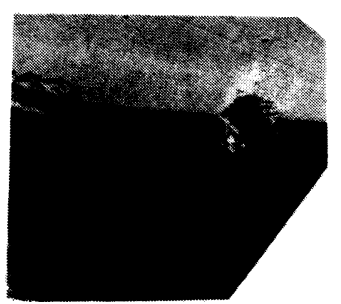

(b) After the cutting test $(100 \mathrm{~m} / \mathrm{min}, 30 \mathrm{~s})$ assisted with burr removing tool

Fig. 7 Decrease of boundary notch by the burr remov. ing tool Cutting conditions are the same as in Fig. 1

めの有効な対策になるであろう.

\section{4. ま と め}

（1） セラミックエ具でステンレス鋼を切削すると 著しい境界損傷が起こる。

（2）この場合の境界損傷増大の主原因は切削バリ である。

（3）したがって，アプローチ角の増大, 工具切れ刃 ランド幅の減少，バリとり切削等によってバリの 生成を抑制すれば境界損傷は減少する。

\section{参考 文 献}

1）まとめたものとしては, 竹山秀彦, 機械の研究, 17, 1(1965) 41.

2）奥島啓式，人見勝人：切削におけるかえりの現象について (II), 精密機械, 24, 9 (1958) 470.

3) J. Vigneau: Ann. CIRP, 31, 1, (1982) 35. 


\section{微小角度傾斜ジグの開発*}

柴 和 男** 清 水正美*** 宮下政 和

Key words: angular displacement, hydrostatic bearing, inclination table, servo control, nanometer technology

1.はじめに

近年，材料の結晶軸に対する加工面の角度精度を高 情度に加工することが要求される場合が少なくない。 例光ば，時計に用いられる水晶振動子に抢ける結晶軸 に対するカット角の精度は, 発振周波数の温度特性に 影響を与えるので，カット角を精確に仕上げることが 要求されている。高精度な時計に用いられる矩形 AT 板振動子の水晶では, カット角のばらつきを 10 " 以 下の精度で加工することが要求される。

従来はラッピング・ポリシングにより加工している が，定圧加工であるために作業能率が低く，十分な精 度を得ることも困難であった。

平面研削盤にカット角検査装置を組み込み，オンラ インで水晶板のカット角を修正し研削することによ り, 高精度で高能率な加工を行らために微小角度傾斜 ジグを開発した。傾斜ジグには，研削負荷に耐えられ る剛性と, 1" 以下の角度分解能が要求されるので, 静 圧軸受のすきま制御 ${ }^{2}$ を応用した。試作した傾斜ジグ の特性について報告する。

\section{2. 構 成}

水晶板は切断時にカット角精度が士 $3^{\prime}$ 以下に加工 されているので, 傾斜ジグの動作範囲を $\pm 3^{\prime}$ とした。 㑯斜ジグの大きさは $180(\mathrm{~L}) \times 198(\mathrm{~W}) \times$ $100(\mathrm{H}) \mathrm{mm}$, 傾斜テーブルの面積は $90 \times$ $50 \mathrm{~mm}$ ，すきま制御のための静圧パッドの 中心間距離は $70 \mathrm{~mm}$ である.图 1 亿試作し た傾斜ジグの概略断面図を示す。傾斜テー ブルの左右に独立してすきま制御機構を組

* 原稿受付 昭和 60 年 4 月 19 日. 昭和 59 年 度精機学会秋季大会学術講演会（昭和 59 年 10 月 1 日) にて発表

** 正会員 シチズン時計(株)（田無市本町 6-1-12)

*** シチズン時計(株)

†正会員 シチズン時計(株)(現, 足利工業 大学；足利市大前町 268-1)
み込み, 傾斜テーブルを駆動する機構とした. 傾斜テー ブルの傾きを傾斜計で，垂直方向変位を変位計でそれ ぞれ検出してフィードバックする方式も考兄られる が，機構が複雑になるので上記方式を採用した。

傾斜テーブルは本体に静圧支持されている。コント ローラからの指令電圧と, 傾斜テーブルの変位を検出 する変位計の出力との差は増幅され，サーボ弁を駆動 する、サーボ弁はコントローラからの指令電圧と, 変 位計の出力とが等しくなるように傾斜テーブルを駆動 し, 保持する.

サーボ弁はノズルフラッパ型サーボ弁を使用した。 変位計としては,ターゲットである傾斜テーブルに油 や研削液が付着しても測定に影響のない渦電流型変位 計を使用した。使用した静圧作動油の粘度は $56 \times 10^{-6}$ $\mathrm{m}^{2} / \mathrm{s}$ (at $40^{\circ} \mathrm{C}$ ), 供給圧力は $4 \mathrm{MPa}$ である.

図 2 に傾斜ジグの動作を示すブロック図を示す。補 償回路としては，定常偏差を少なくする目的で位相遅 れー進み回路を用いた。

\section{3、実験結果及び検討}

試作した傾斜ジグの動作範囲は，ループゲイン 600

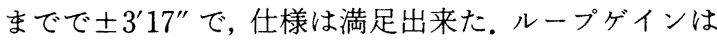
1200 まで上げることが出来たが，その時の動作範囲 は土37”であった。以下では主にループゲインを 200

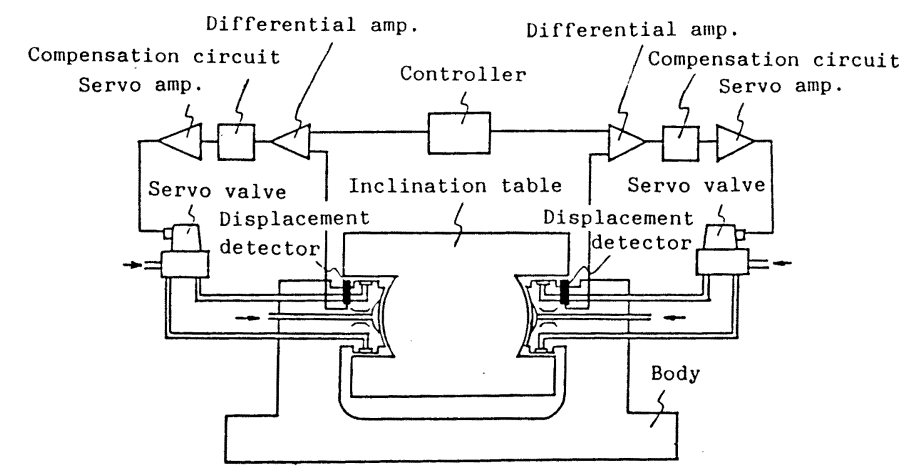

Fig. 1 Schematic construction of minute inclination table 


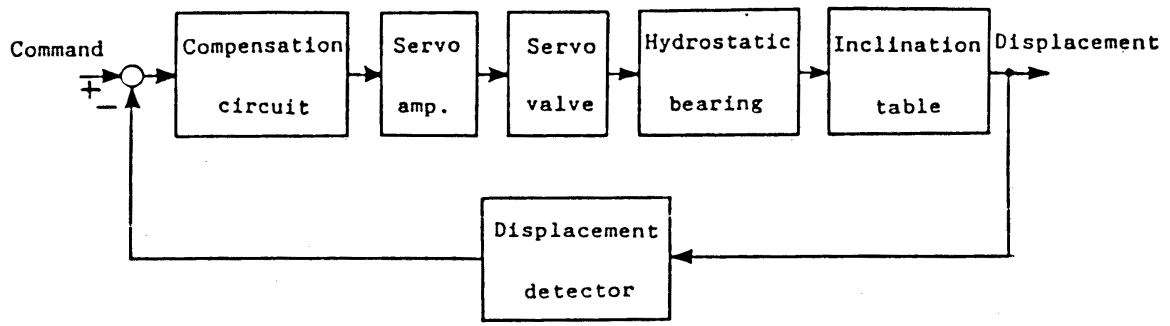

Fig. 2 Block diagram of minute inclination table

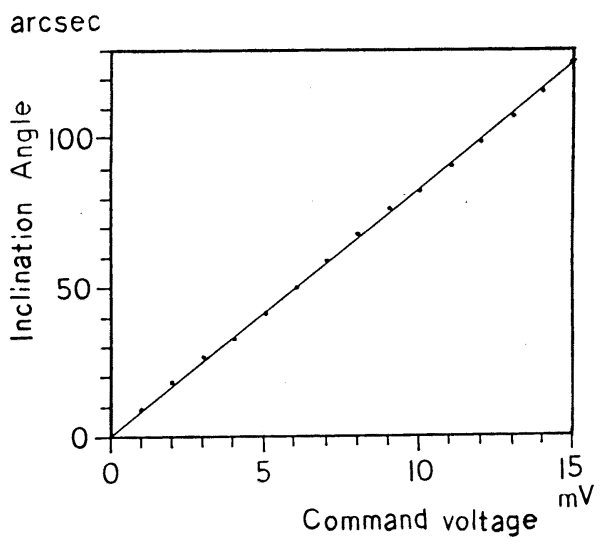

Fig. 3 Command voltage and resulted inclination angle

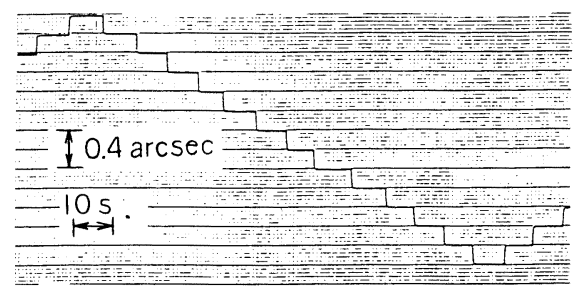

Fig. 4 Response to angular stepwise displacement commands of 0.2 arcsec

とした時のデータを示す。

図 3 に角度指令電圧に対する傾斜テーブルの傾斜角 をレーザ測長器で測定した実測值を示す，角度指令電 圧に対して傾斜角は比例している。実測值が直線から ずれているのは, フィードバック用の変位計のリニア リティ誤差によるものと考えられる。

図 4 にステップ状に角度指令電圧を与えた時の傾斜 テーブルの傾きを示す。傾きは変位計の出力から換算 した。 0.2"ステップで動作していることがわかる。こ れ以下の微小ステップ動作は, 使用した变位計の分解 能の影響で出来なかった。

システムの分解能を確認するために，分解能の高い 変位計（静電容量型变位計）をフィードバックに使用 して，微小ステップ動作を行った．図 5 に測定結果を

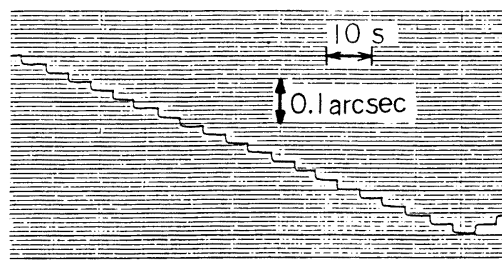

Fig. 5 Response to angular stepwise displacement commands of 0.02 arcsec

$\mathrm{N} / \mu \mathrm{m}$

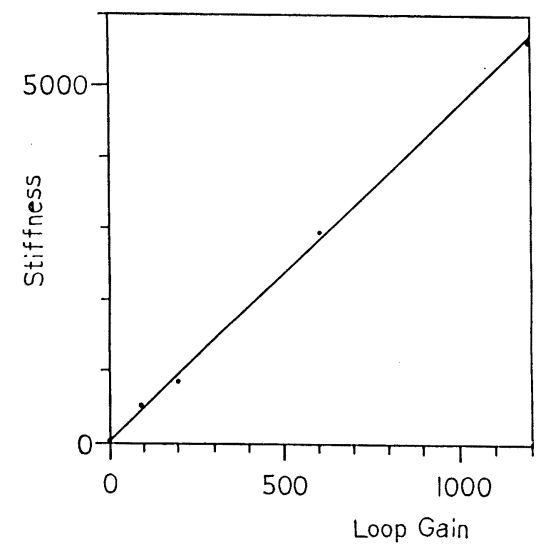

Fig. 6 Loop gain and stiffness in vertical direction

示す. 図 4 と同様に変位計の出力を角度に換算してい る. 1 ステップは $0.02 "$ に相当し,フィードバック用変 位計の分解能が改善されれば， $0.02 "$ の角度分解能が 得られることがわかった。

図 6 は傾斜テーブルを水平に保って中央に垂直荷重 を加えた時の静剛性を，ループゲインをパラメータと して示したものである。ループゲインが零といらのは, フィードバックをしない時を意味している。静剛性は ループゲインに比例して向上しているのがわかる. ループゲインが 200 の時の静剛性は $900 \mathrm{~N} / \mu \mathrm{m}$ であ る. 別な実験によれば水晶をダイヤモンド砥石で切込 み $5 \mu \mathrm{m}$, 送り速度 $10 \mathrm{~mm} / \mathrm{min}$ で研削した時の研削抵 抗は $10 \mathrm{~N}$ 以下であった。研削力に比較して十分な剛 性が得られたと考えられる。また，傾斜テーブルを動 


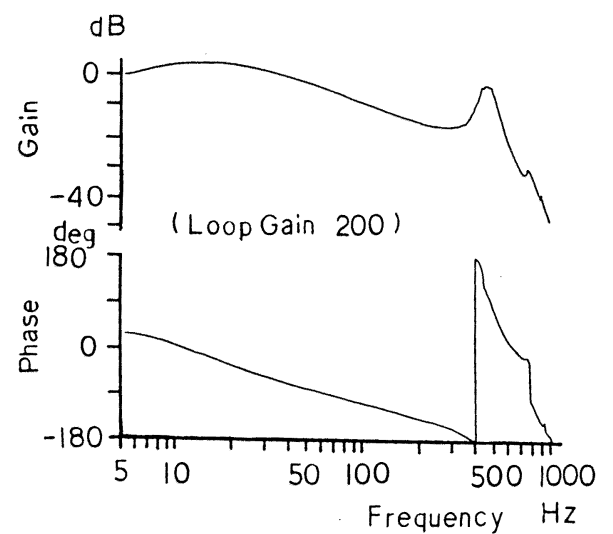

Fig. 7 Frequency characteristics of the system

作範囲の $40 \%$ まで傾けても,垂直方向の静剛性は変わ らなかった。

図 7 に角度指令信号の代わりに正弦波を入力した時 の周波数特性を示す。バンド幅は $60 \mathrm{~Hz}$ である. 500 $\mathrm{H} z$ 付近のピークはサーボ弁の共振によるものであ る.
4. ま と め

静圧軸受のすきま制御を応用した微小角度傾斜ジグ を試作した。ループゲインを 200 とした時, 次の性能 が得られた。

（1）動作範囲士 $3^{\prime} 17^{\prime \prime}$ ，分解能 $0.2^{\prime \prime}$

（2）静剛性 $900 \mathrm{~N} / \mu \mathrm{m}$

また，フィードバック用変位計の分解能を上げるこ とにより，傾斜角の分解能を 1 けた向上させることが 出来た。

今後は動剛性の測定を行うと共に, 研削加工実験を 行ら予定である.

最後に日ごろ御指導を頂いている都立大・金井先生 に感謝申し上げます。また，実験に協力されたシチズ ン時計・高橋氏に謝意を表します。

\section{参 考 文 献}

1）柴 和男ほか：微小角度傾斜ジグ, 昭和 59 年度精機学会 秋季大会学術講演会講演論文集 (1984) 213 。

2）金井彰ほか：静圧軸受のすきま制御による位置決め機 構の特性, 昭和 54 年度精機学会春季大会学術講演会講演 論文集（1979） 387 .

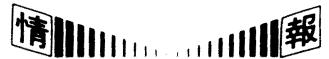

(p. 873 より続く)

[采励賞] $\nabla$ 非線形ばね特性・異方性をるつ回転軸の 振動に関する研究＝池田(名大助手)， 浮動ヘッドスラ イダーの薄膜気体潤滑に関する研究二大久保俊文（日本 電信電話電気通信研究所磁気記録研究室員)， $\nabla$ 軽水炉一 次系ステンレス鋼配管の LBB 成立性評価に関する解析 手法の開発=鹿島光一（電力中央研究所エネルギ研究所 機械部高温材料研究室員)，液体で部分的に満たされた 中空回転軸系の自動振動に関する研究＝金子成彦（東京 大学助教授), $\nabla$ 非白色非定常入力に対する非線形の不規 則振動解析法に関する研究二木村康治（東京工業大学助 手)， $\nabla$ 大形急速圧縮装置の設計・試作とこれを用いた ディーゼル噴霧・火災に関する研究＝小林治樹（東京工 業大学助手), $\nabla$ 乱流はく離泡の非定常挙動および構造に 関する研究 =佐々木久郎(秋田大学助手)， 空どうを伴 ら流れの非線形解析に関する研究=佐藤恵一（金沢工業 大学教授)， $\nabla$ 高温構造物の余寿命評価技術に関する研 究二桜井茂雄(日立製作所機械研究所研究員)， $\nabla$ 三次元 翼間圧縮性乱流解析に関する研究＝鹿野芳雄（日立製作 所機械研究所研究員)， $\nabla$ 接着継手の強度設計に関する研
究二杉林俊雄(東京工業大学助手), $\nabla$ 二次流れを伴う三 次元流動場の数值解析に関する研究＝中山顕（静岡大学

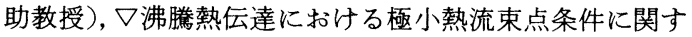
る研究 = 西尾茂文 (東京大学助教授)， $\nabla$ 流路解法逆問題 設計手法を用いた高負荷軸流ガスタービン翼列に関する 研究 $=$ 橋本啓介（川崎重工業ジェットエンジン事業部第 二技術部員), $\nabla$ ガソリン機関の熱発生遅れ期間のサイク ル変動低減による燃焼の安定化に関する研究＝浜井力五 (日産自動車中央研究所動力機械研究所第一研究員), $\nabla$ 鉄道車両の運動力学に関する研究二藤岡健彦（東京大学 助教授), $\nabla$ はく離を伴らねじり振動翼の非定常空力特性 に関する研究=藤本一郎(東京大学助手)， $\nabla$ 高温熱交換 器における胴側ガスの流動と伝熱に関する研究二松島均 (日立製作所機械研究所研究員)， $\nabla$ ターボ機械などの騒 音分析予測に関する研究＝丸田芳幸（荏原総合研究所第 三研究室主任), $\nabla$ 静王形気体ジャーナル軸受の性能改善 に関する研究 $=$ 吉本成香 (東京理科大学助手).

（服部 敏夫） 